\title{
The Effect of Board Composition on Conservatism: Empirical Evidence from Tehran Stock Exchange (TSE)
}

\author{
*Keramat Ollah Heydari Rostami ${ }^{1}$, Hamed Omrani ${ }^{1}$, Saber Samadi ${ }^{1}$, Hamid Asadzadeh ${ }^{1}$, Ahmad Kazemi \\ Margavi $^{1}$, Hemad Nazari ${ }^{2}$ \\ ${ }^{1}$ University of Tehran, Iran \\ ${ }^{2}$ University of Tehran Azad Oloomva Tahghighat, Iran \\ *heydarykeramat@gmail.com
}

\begin{abstract}
Conservative is misinterpreted as capturing accountants 'tendency to require higher degree of verification for recognizing good news than bad news in financial statements. Under this interpretation of conservatism, earnings reflect bad news more quickly than good news. By using firms' stock returns to measure news, the asymmetric time lineless of recognizing good news and bad news can be examined as a measure of conservative behavior and as them an in question of this research in Irani and capital market. This research examines effect of composition of the board of directors of the companies listed in Tehran Stock Exchange (TSE) on conservative. Data analysis for seven years (2003-2010) shows that companies with a more in dependent board are more conservative. It means that these companies report bad news more timeliness than good news. The results of the research results confirm and reinforce previous researches.
\end{abstract}

Key Words: Board of directors, Bad news, Conservatism, Good News, TSE

\section{Introduction}

This research on the subjectof conservatism has been concentrated, that the issue of the important issues of financial research. For this purpose to find an answer for this question that if there is any relationship between the composition of the board of directors of the companies listed in Tehran stock exchange and conservatism and if there is that there is directly or reverse relationship.Managers are motivated to hide losses to avoid expulsion before the end of being retried. Bear of losses, or to accept projects with negative net present value to can motivate shareholders to dismiss the director of the strategic. Using conservatism identified as losses speed and for the board of directors and shareholders evidence of inefficiency and operations for their loss to the pursuit and investigates the reasons for its alert. Because of such a discrepancy between managers interests, shareholders and other capital funders, corporate governance structures has been guided by the contracts effective supervision and management behavior, to reduce representative problems (Fama \& Jensen, 1983). Literature in the field of research in corporate governance emphasis on the role of the members of out directores of the board of directors in reducing problems caused by the representation issue, through observation and guidance of executive management behavior designed to encourage (Fama \& Jensen, 1983).

The board of directors as part of the main part of corporate governance beyond the management and shareholders played a major factor in charge of the stakeholders. The truth is that the companies, most managers pursuing their own interests instead of stakeholders interests (Scott, 2009). To solve this problem, there are two ways: first, to encourage managers to do the expected reward for them, "The second, thestrengthen of board of directors is a way to control the performance of managers (Scott, 2009). According to researches and the theory predict, whatever the board of directors has more independence, the better control the list of financial quality with be done. Conservatism means that it should be reported the least value of the assets and the most valuable value for debt. Revenues should not be identified soon but later and costs should not be identified as soon as possible. Hence, for the researcher this question appears whether the composition of the board of directors and the conservatism has relation. To answer this question Researcher should find answers for questions as follows: is there any relation between the timeliness of recognition of the bad news reflected in profit and the percent of out director's managers in the board of 
directors. Is there any relation between the good news reflected in profit and thepercent of out director's managers in the board of directors?

\section{Literature Review}

The board of directors has an important role in a company and the Organization. The board of directors are responsible of supervising the quality of the existing information in that case they control senior managers to conduct right and to ensure that their activities are in accordance are in line with the interests of stockholders, investors, creditors and other voters who part the company with which are in contact. The composition and size of the Directory Company is an issue that is interested in recent years in International researches (Weisbach, 1998; Yermack, 1996). The existing research literature in contact with the supervision of the directors and the quality of accounting shows that the fraud is less in the financial statements of companies with number of members of out directors of board (Beasley, 1996; Dechow et al, 1996; Peasnell et al, 2000; klein, 2002).

It seems the board of directors has a strategic role in the company and in supervision of the executive managers in order to protect shareholders. With regard to the independence of out directors, it is expected that higher percent ofthese members will lead to better guiding; including methods adopted more conservative volunteers' methods in favor of identifying time of revenues. Beasley (1996); Dechow (1996); Farber (2005) are presented evidence that the companies with the board of directors with the majority of the members of out directors, less involved in accounting fraud. Beekes et al (2004) examines Relations between the percent of out directors of the board with conservatism. Ahmed \& Duellman (2007) with the use of Basu model showed that higher percent of executive managers of the board of directors lead to the decrease conservatism. Effectiveness of The board of directors also can depend on the composition of the board of directors. One theory is that in the board of directors that considerable of them are members of out directors, sacrificial supervision is done on the Management, and therefore, can limit management authority. Byrd \& Hickman (1992), and Rosenstein et al (1990) based on this confusion also noticed a positive relationship between out directors percent of the members of the board of directors and company performance. There are of researches show that a high level of out directors is inefficient in the board of directors, and have known it as due to change of strategic activities, the lack of business literacy to be effective and lack of true independence. The foundation of this view is that the members of the board of out directors usually a little bit information about the company and the necessary practical (Agrawal \& Kroeber, 1996).

Cadbury (1992) has recommended that the board of directors, there should be at least three members of out directors or non-execution in the board can be effective on the decisions of the board of directors. The board of directors has the highest authority in controlling system and the implementation of the dual role Ratification of the company. The board of directors role is to control and regulate Company's Management behavior to make sure that management follow shareholders' interests (Fama \& Jensen, 1983). As long as there is less control from out of the company (for instance from financial markets), in this case there can be brought a domestic control insupervisory mechanism in the form of the required in the composition of the board of directors. More members of the out directors in the structure of the board of directors, more control and influence on the independent company can be done.

It have been studied and determined in former researches that out directors have impact on a wide range of decisions such as dismiss of SEO (Weisbach, 1988), proposed bid (Byrd \& Hickman, 1992) and resistance to paying the huge profits for acquiring major shares of other companies. In addition, many researchers have been emphasis on the role of out directores in the board of directors through observation and guidance on executive management behavior in reducing the issues caused by representation problems (Fama \& Jensen, 1983). Conclude that the board of directors that the members of non-executive are more, are more in line with shareholders' interests and more likely to prevent poor performance of the board. Numerous studies show that existence of those non-executive members in the board of directors has a positive effect on the value of the company and wealth of Shareholders.

Hypothesis: Skinner (1994), Trueman (1997), Beekes et.al (2004), Lafond \& Roychowdhury (2008) believe that managers have much motivation to report bad news because they want to safe themselves from legal 
responsibility. The result is that, it is expected that companies with good structure of corporate governance with more percent of out directors have been more conservative and reflect bad news more timeliness in profit.

H1: there is a positive and significant relationship between the timeliness of bad news and the percentage of out directors.

H2: there is a negative and significant relationship between the timeliness of good news and the percentage of out directors.

Regard to the role and importance of to non-executive managers in the composition of the board of directors and the audit committee that has been fabricated in the principles of corporate governance by the Iranian stock \& exchange organization(SEO) has been accepted, the results of this investigation will show to some extent that weather the presence of the members of non- executive in the composition of the board of directors is in connection with the level of companies' accounting information quality or not?

\section{Methodology}

The data used in this study are from two databases: the information as the financial and information related to the output value and stock day price. Major parts of the information related to financial statements have been used from the software "RahavardNovin". In addition, some parts of the information have been used from the "TadbirPardaz" database. Information related to the return and the day values of the shares have been used from the database of "TadbirPardaz". It is used Spss 18 for analyzing data and results. In some cases, it has used the website www.rdis.com's database that is owned by Islamic Project and study management center, for using financial statements. Date for returns and price of exact day of a share, it has used the RahavardNovin software database. Data collected were import in excel data files and after collecting all needed data, all calculations for analyzing were done. For final analyzing of data and results, it has used Spss 18.

The period of this study is 2003 to 2010 and it is examined in Tehran Stock Exchange (TSE). It is known that all objects that have one common quality are called statistic society and in this study, the statistic society is all companies listed in TSE. For choosing from society and collecting sample, there are some qualifications as below:

- All companies should be listed in TSE before 2003.

- Because the fiscal year in Iran ends in 19 March, all should this fiscal year.

- They should not have changed their operations or their end of fiscal year.

- For calculating dependent "conservatism", it needs to find and calculate market value of company's equity in end of year, so company's shares should be transacted in February and March (Esfand, the last month in Iran calendar).

Method of sampling is judicative. By these qualifications, the sample of 61 company's means of 488 companyyears in the period of 2003 to 2010 is selected. Following Beekes et al. (2004) we will use the Basu (1997) reverse regression model between earnings per share and stock returns. For this reason, we have estimated 12-month stock returns over the fiscal year in order to proxy for the news about a firm's performance that is publicly available. Basu (1997) introduces adummyvariable (D) in the reverse regression model based on the assumption that earnings are expected to be highly correlated with market returns in periods of depression in market values than in periods of prosperity on market values. This qualitative variable is given the value of one (1) when returns are negative and zero (0) if they are positive. Under these assumptions, the final form of the Basu (1997) model is as follows:

Model 1: Eit=b1+b2*Rit+b3*D+b4*Rit*D+eit

$E_{i t}=$ accounting earnings for the year $\mathrm{t}$ and the company $\mathrm{i}$

$R_{i t}=$ year return for the year $\mathrm{t}$ and the company $\mathrm{i}$ 
$D_{i t}=$ This qualitative variable is given the value of one (1) when returns are negative and zero (0) if they are positive

The regression coefficients b2 and b4 can be seen as the reaction of earnings to "good news" and "bad news" respectively. An indication of conservatism could be a positive sign of the coefficient b4 as well as the increase of the coefficient of multiple determinations in periods of "bad news". The intercept of the regression equation, b1, will be expected to have a negative sign if conservatism affects earnings, otherwise it will have a positive sign. Finally, the coefficient b3 may be explained as a setback of previous year's market information to current value decreases. "When b3 is positive over provisioning is reversed as a prior year adjustment. When b3 is negative we infer that deferred income recognition is scaled down". Following Beekes et al. (2004) we extended the Basu (1997) model to examine the association between accounting quality and board composition, by introducing a dummy variable OD into the model which takes the value of one (1) if the number of outside board members is above the sample median and zero (0) otherwise. The new variable then is interacted with the other variables in the standard Basu (1997) model as it is depicted in the following equation:

\section{Model 2: EPSit=b0+b1Rit+b2Dit+b3Rit*Dit+b4ODit+b5Dit*OD+b6Rit*ODit+b7Rit*Dit*ODit+eit}

Where $\mathrm{R}_{\mathrm{it}}$ is the raw stock return of firm i during the fiscal year t. EPS $\mathrm{it}_{\mathrm{it}}$ is the annual earnings per share of firm i for year $t$. $D_{i t}$ is a dummy variable taking the value of (1) if $R_{i t}$ is negative and zero otherwise. $O D_{i t}$ is a dummy variable taking the value of (1) if the number of outside members on the board of directors is above the sample median and zero otherwise. It is expected that firms with above the sample median number of outside directors (OD equals1) will be better monitors of business activities and adopt a conservative reporting attitude due to agreater presence of outsiders. Hypothesis 3 declares that firms with an increased proportion of outside directors on the board will be more conservative than firms with a small fraction of outside directors.We expect this to be represented by a significant positive coefficient on the $\mathrm{R}^{*} \mathrm{D}^{*} \mathrm{OD}$ interactionterm. Finally, hypothesis 4 predicts that firms with above the median level of outsiders on the boardwill be more conservative on the recognition of good news. If this is true, then the coefficient $b_{1}$ which captures the timeliness of good news (when OD equals zero) will be larger than (b1 + b6) and statistically significant. Therefore, $b 6$ will be negative and significant. Beyond the aforementioned analysis, we will reestimate model 2 by including the control variables, advantage, firm size options.

Consequently, model 3 becomes:

Model 3: $\mathrm{EPS}_{\mathrm{it}}=\mathrm{b}_{0}+\mathrm{b}_{1} \mathrm{R}_{\mathrm{it}}+\mathrm{b}_{2} \mathrm{D}_{\mathrm{it}}+\mathrm{b}_{3} \mathrm{R}_{\mathrm{it}}{ }^{*} \mathrm{D}_{\mathrm{it}}+\mathrm{b}_{4} \mathrm{OD}_{\mathrm{it}}+\mathrm{b}_{5} \mathrm{D}_{\mathrm{it}}{ }^{*} \mathrm{OD}_{\mathrm{it}}+\mathrm{b}_{6} \mathrm{R}_{\mathrm{it}}{ }^{*} O \mathrm{D}_{\mathrm{it}}+\mathrm{b}_{7} \mathrm{R}_{\mathrm{it}}{ }^{*} \mathrm{D}_{\mathrm{it}}{ }^{*} \mathrm{OD}_{\mathrm{it}}+\mathrm{b}_{8} \mathrm{LEV}_{\mathrm{it}}+\mathrm{b}_{9} \mathrm{SIZE}_{\mathrm{it}}+\mathrm{e}_{\mathrm{it}}$

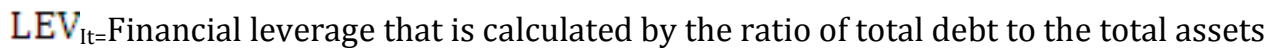

$\mathrm{SIZE}_{\mathrm{lt}}=$ Company's size is the natural algorithm of total assets in end of the year

\section{Results}

\section{Descriptive statistics and correlations}

Table 1: Descriptive statistics of the sample variables from 2003 to 2010

\begin{tabular}{llll}
\hline Coefficient & average & standard deviation & median \\
\hline$R_{i, t}$ & 0.41 & 0.77 & 0.375 \\
EPS & 890 & 991 & 883 \\
OUTDIR $_{i, t}$ & 0.54 & 0.20 & 0.6 \\
Lev $_{i, t}$ & 0.74 & 0.37 & 0.7 \\
SIZEi,t & 5.76 & 0.58 & 5.69 \\
\hline
\end{tabular}


Sample consists of 61 companies listed in the Tehran Stock Exchange from 2003 to 2010. March fiscal year end firms are included in the sample. Rit is the raw stock returns of firm $i$ at the end of the fiscal year and Pit is the stock price of each firm at the end of the fiscal year. EPS it is the annual earnings per share of firm i for year t. OUT DIR it is the ratio of outside directors defined as those who are not an active or retired employee of the firm, do not have any close business ties and are not representatives of a major shareholder of the firm. LEV it is the financial advantage measured as the ratio of total debt to total assets. The SIZE it of the firm is measured as the natural logarithm of firm's total assets at the end of the fiscal year.

Table 2: Pearson Correlation coefficients among sample variables (2003-2010)

\begin{tabular}{llllll}
\hline coefficient & R & EPS & OUTDIR & LEV & SIZE \\
\hline $\mathrm{R}$ & 1 & $.286^{* *}$ & -.015 & .032 & -.008 \\
& & .000 & .763 & .505 & .875 \\
EPS & $.286^{* *}$ & 1 & $.128^{* *}$ & .052 & -.048 \\
& .000 & & .008 & .288 & .318 \\
OUTDIR & -.015 & $.128^{* *}$ & 1 & -.090 & $.193^{* *}$ \\
& .763 & .008 & & .064 & .000 \\
LEV & .032 & .052 & -.090 & 1 & $-.145^{* *}$ \\
& .505 & .288 & .064 & & .003 \\
SIZE & -.008 & -.048 & $.193^{* *}$ & $-.145^{* *}$ & 1 \\
& .875 & .318 & .000 & .003 & \\
\hline
\end{tabular}

Pearson correlation coefficients of the sample variables. P-values are in the parenthesis. ${ }^{*}, * *, * * *$ Significance at a $=1 \%, 5 \%$ and $10 \%$ respectively.Sample consists of 61 companies listed in the Tehran Stock Exchange from 2003 to 2010. March fiscal year end firms are included in the sample. $R_{i t}$ is the raw stock returns of firm $i$ at the end of the fiscal year and Pit is the stock price of each firm at the end of the fiscal year. EPS it $_{\text {is }}$ the annual earnings per share of firm i for year t. OUTDIR it is the ratio of outside directors defined as those who are not an active or retired employee of the firm, do not have any close business ties and are not representatives of a major shareholder of the firm. $\mathrm{LEV}_{i t}$ is the financial advantage measured as the ratio of total debt to total assets. The SIZE it of the firm is measured as the natural logarithm of firm's total assets at the end of the fiscal year.

Results on conservatism and board composition: The relative results are presented in Table 3. Model 1 is the standard Basu (1997) model that examines the timeliness of good and bad news. Coefficient b1 is insignificant indicating that firms are not timely reporters of good news. On the contrary, coefficient b3 is positive and significant suggesting that bad news is reflected in earnings on a timelier basis. Models 1 and 2 include the additional dummy variable OD and its interaction term with negative returns. OD takes the value of one (1) if the number of outside directors serving on the board is above the sample median and zero otherwise. In both models coefficient $b 7\left(O D^{*} D^{*} R\right)$ is positive and significant as it was predicted, thus verifying hypothesis 1 ( 0.91 and 0.88 respectively). This result suggests that there is a greater timeliness in earnings relative to bad news in firms with above the median level of outsiders. Put it another way, there is lower sensitivity to bad news in firms with low outsider representation. However, the results provided by models $2 \mathrm{~d}, 2 \mathrm{e}$ and $2 \mathrm{f}$ do not support our fourth hypothesis. Coefficient b6, which captures the timeliness of good news, is insignificant in all mode specifications. This actually means that there is no incremental improvement in the speed of integrating good news into earnings for firms with increased board independence. Still the fact that b7 is significant confirms that outside directors influence financial reporting only in terms of recognition of bad news. These results are consistent to Beekes et al. (2004) and Lafond and Roychowdhury (2008) and Bushman et al. (2004a) who found a low timeliness measure of Greek firms.

Sample consists of 61 companies listed in the Tehran Stock Exchange from 2003 to 2010. March fiscal year end firms are included in the sample. $R_{i t}$ is the raw stock returns of firm $i$ at the end of the fiscal year and Pit is the stock price of each firm at the end of the fiscal year. Dit is a dummy variable taking the value of (1) if $R_{\text {it }}$ is negative and zero otherwise. $O D_{i t}$ is a dummy variable taking the value of (1) if the number of outsider members on the board of directors is above the sample median and zero otherwise. $L_{E V} V_{i t}$ is the financial 
advantage measured as the ratio of total debt to total assets. The SIZE $\mathrm{E}_{\text {it }}$ of the firm is measured as the natural logarithm of firm's total assets at the end of the fiscal year.

Table 3: the relation between earnings conservatism and board composition

\begin{tabular}{|c|c|c|c|c|c|c|c|c|c|c|c|c|}
\hline Model & $\mathbf{b}_{0}$ & $\mathrm{R}$ & $D$ & $\mathrm{R} * \mathrm{D}$ & OD & $\begin{array}{l}\mathrm{D}: \\
\mathrm{OD}\end{array}$ & $\begin{array}{l}\mathrm{R} \& \\
\mathrm{OD}\end{array}$ & $\begin{array}{l}\text { OD } \approx \\
D \approx R\end{array}$ & LEV & SIZE & F - Stat & $\mathrm{R} 2-\mathrm{Ad}$ \\
\hline $\begin{array}{l}1 \\
\mathrm{~T} \\
\text { sig }\end{array}$ & $\begin{array}{l}665.78 \\
(14.739) \\
(0.000)\end{array}$ & $\begin{array}{l}-1.994 \\
(-1.557) \\
(0.118)\end{array}$ & $\begin{array}{l}253.9 \\
(2.544) \\
(0.011)\end{array}$ & $\begin{array}{l}55.09 \\
(16.019) \\
(0.000)\end{array}$ & & & & & & & $\begin{array}{l}157.73 \\
(0.000)\end{array}$ & 0.532 \\
\hline $\begin{array}{l}2 \\
\mathrm{~T}\end{array}$ & $\begin{array}{l}615.1 \\
(11.04)\end{array}$ & $\begin{array}{l}-2.019 \\
(-4.683)\end{array}$ & $\begin{array}{l}270.91 \\
(2.673)\end{array}$ & $\begin{array}{l}55 \\
(15.338)\end{array}$ & $\begin{array}{l}153 \\
(2.126)\end{array}$ & $\begin{array}{l}-206.84 \\
(-1.577)\end{array}$ & $\begin{array}{l}-3.757 \\
(-0.854)\end{array}$ & $\begin{array}{l}6.83 \\
(4.384)\end{array}$ & & & 68.648 & 0.534 \\
\hline $\begin{array}{l}\text { sig } \\
3 \\
T\end{array}$ & $\begin{array}{l}(0.000) \\
838.136 \\
(2.418)\end{array}$ & $\begin{array}{l}(0.000) \\
2.02 \\
(4.676)\end{array}$ & $\begin{array}{l}(0.008) \\
273 \\
(2.686)\end{array}$ & $\begin{array}{l}(0.000) \\
55 \\
(15.295)\end{array}$ & $\begin{array}{l}(0.034) \\
149.8 \\
(2.030)\end{array}$ & $\begin{array}{l}(0.12) \\
-209.26 \\
(-1.566)\end{array}$ & $\begin{array}{l}(0.393) \\
-3.86 \\
(-0.875)\end{array}$ & $\begin{array}{l}(0.000) \\
6.83 \\
(4.385)\end{array}$ & $\begin{array}{l}-4.128 \\
(-0.046)\end{array}$ & $\begin{array}{c}-37.641 \\
(-0.667)\end{array}$ & $\begin{array}{l}(0.000) \\
53.242\end{array}$ & 0.532 \\
\hline $\begin{array}{l}1 \\
\text { sig }\end{array}$ & $\begin{array}{l}(2.418) \\
(0.016)\end{array}$ & $\begin{array}{l}(4.6 / 6) \\
(0.000)\end{array}$ & $\begin{array}{l}(2.080) \\
(0.008)\end{array}$ & $(0.000)$ & $\begin{array}{l}(2.030) \\
(0.043)\end{array}$ & $\begin{array}{l}-1.5000) \\
(0.118)\end{array}$ & $(0.382)$ & $(0.000)$ & $(0.963)$ & $(0.499)$ & $(0.000)$ & \\
\hline
\end{tabular}

Meaningfulness of the regression functions: According to table four, because calculated F-stat of the models in 95\% confidence $(\alpha=5 \%)$ in all models are more than F-stat in statistical table, so $H_{0}$ that says regression model is not significant, is rejected. It is obvious that by rejecting $H_{0}$, regression models are significant.

Table 4: Regression Results

\begin{tabular}{rlrrrrr}
\hline \multirow{2}{*}{ Model } & & Sum of squares & df & Average of squares & F-stat & p-value \\
\hline \multirow{2}{*}{1} & regression & 199.50 & 3 & 66.50 & 157.73 & 0.000 \\
& errors & 172.85 & 410 & 0.42 & & \\
& total & 372.35 & 413 & & & \\
& regression & 201.83 & 7 & 28.83 & 68.648 & \\
& errors & 170.52 & 406 & 0.42 & & 0.000 \\
& total & 372.35 & 413 & & & \\
3 & regression & 202 & 9 & 22.45 & 53.24 & \\
& errors & 170.3 & 404 & 0.42 & & 0.000 \\
\hline
\end{tabular}

Auto correlation: Durbin Watson stat is used to identify of being or not the auto correlation in residuals. Therefore, there are:

$\mathrm{H}_{0}=$ there is auto regression in residuals

$\mathrm{H}_{1}=$ there is not auto regression in residuals

If this stat is above 1.5 and less than $2.5, \mathrm{H}_{0}$ is rejected and $\mathrm{H}_{1}$ is admitted.

Table 5: Results of Durbin Watson

\begin{tabular}{lllll}
\hline model & R & R square & Adjusted R square & Durbin Watson stat \\
\hline 1 & $0.732^{\mathrm{a}}$ & 0.536 & 0.532 & 1.607 \\
2 & $0.736^{\mathrm{a}}$ & 0.542 & 0.534 & 1.602 \\
3 & $0.737^{\mathrm{a}}$ & 0.543 & 0.532 & 1.594 \\
\hline
\end{tabular}

a. Predictors: (Constant), size, $r^{*} d, O D$, lev, $r, d, d^{*} O D, r^{*} O D, r^{*} d^{*} O D$

b. Dependent Variable: eps

Therefore, as table 5 shows, Durbin Watson stat in all models are around 1.6 and it shows $\mathrm{H}_{0}$ is rejected and $\mathrm{H}_{1}$ is accepted. 
Normality distribution of errors by average of zero for hypo $1 \& 2$ : As graph 1, 2 and 3 show distribution of errors is normal. Standard deviation of distribution of errors is $0.996,0.991$ and 0.989 for models 1,2 and 3 respectively.

\section{Graph 1}

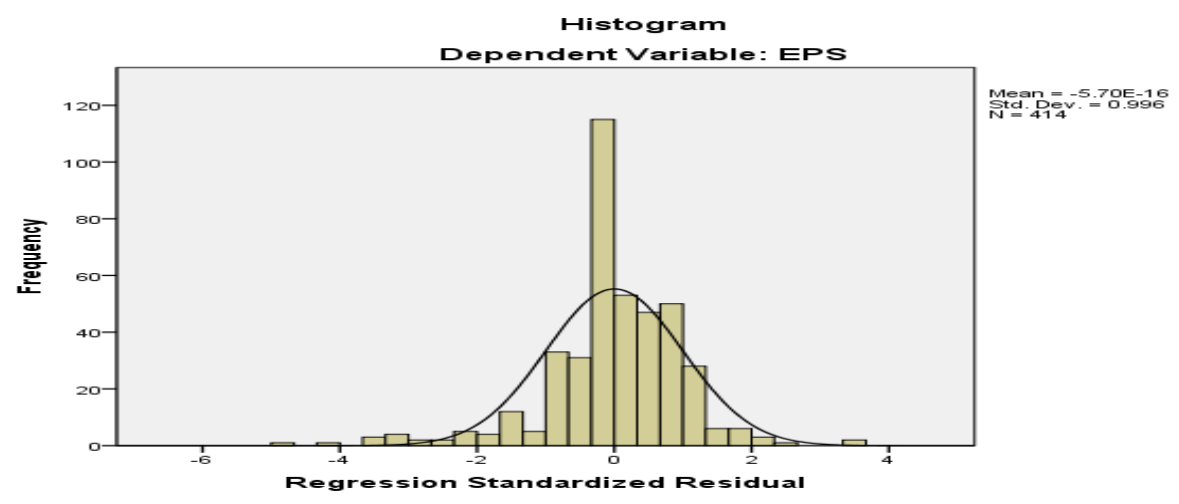

\section{Graph 2}

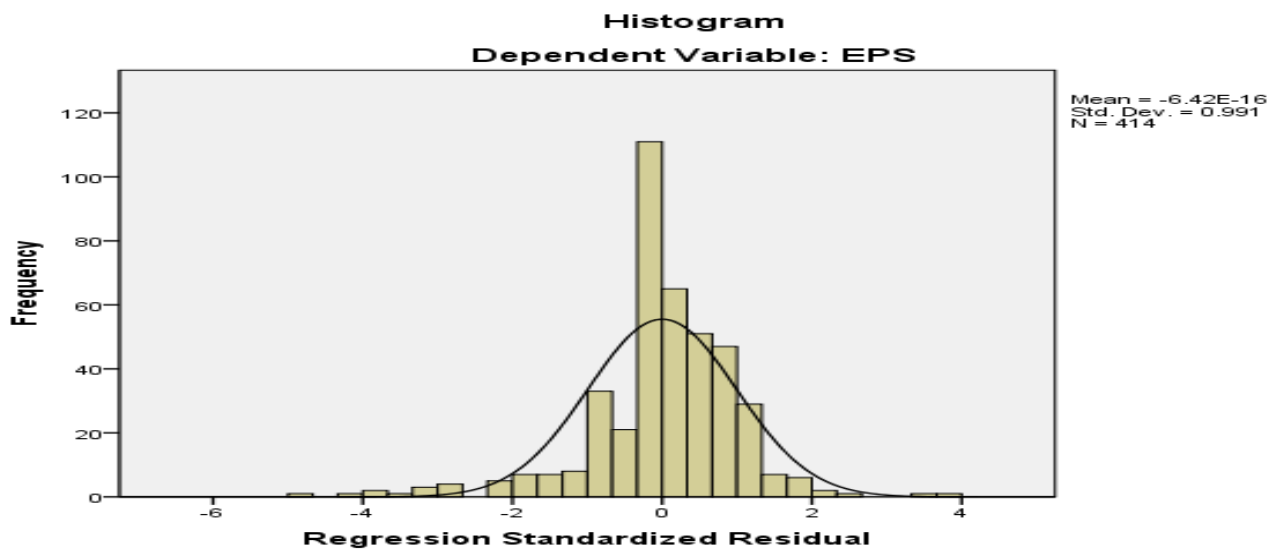

\section{Graph 3}

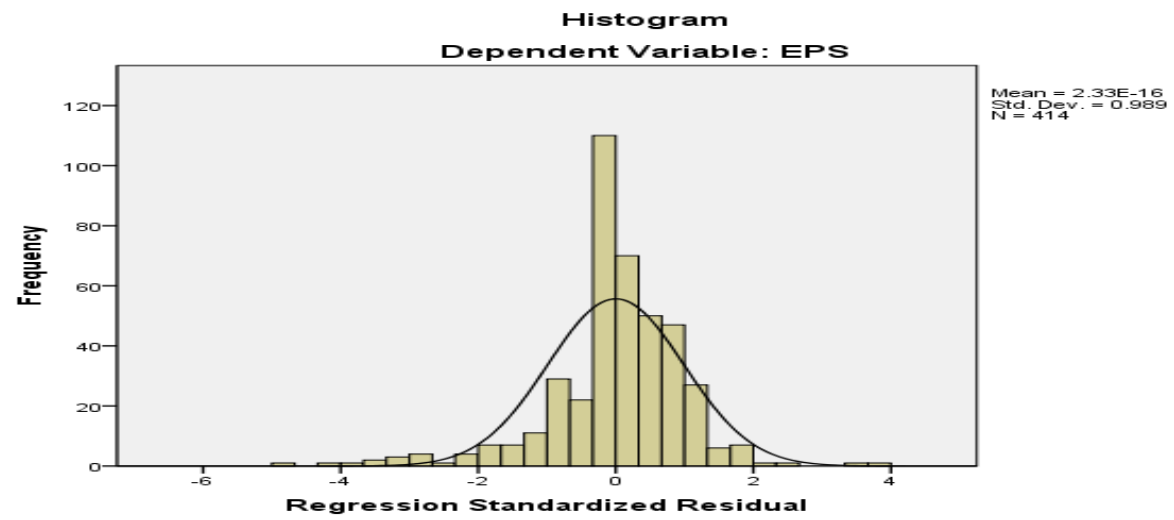

\section{Concluding Remarks and Future Research}

The aim of this paper was to examine how the informational quality of annual accounting earnings,varies according to the composition of the board of directors, within the Iran capital market.For this reason it is selected a sample of 61 companies all listed in the Tehran Stock Exchange, withfull financial data and 
information on the structure of the board of directors from 2003 to 2010.The empirical findings suggest that the number of outside directors serving on the board affects earnings relative to bad news in firms with above the median level of outsiders. This actually means that there is no incremental improvement in the speed of recognizing good news into earnings for firms with increased board independence. However, two limitations need to be mentioned. First, the empirical tests conducted in this study may suffer from an omitted variables problem. The second limitation arises from possible data measurement errors. Despite the aforementioned limitations, our findings could be proved valuable to investors, managers and regulators since they have implications for all these related parties. Financial statement information is the main path managers use in order to communicate significant information to investors. If this information is reported in a conservative manner, it enables market participants to evaluate a firm's future accounting earnings and equity. Some further issues need to be examined. First, it will be interesting to consider the effect of audit committees on the quality of published accounting earnings. Furthermore, some variables such as returns have more than one definition like the one the returns of buying - holding shares and these other definition can use in other study. In addition, it can be studied in different industries.

\section{References}

Agrawal, A. \& Kroeber, C. R. (1996). Firm performance and mechanisms to control agency problems between managers and shareholders. Journal of Financial and Quantitative Analysis, 31, 377-397.

Ahmed, A. S. \& Duellman, S. (2007). Evidence on the role of accounting conservatism in corporate governance. Journal of Accounting and Economics, 43, 411-437.

Basu, S. (1997).The conservatism principle and the asymmetric timeliness of earnings. J. Account. Econ., 24, 337.

Beasley, M. S. (1996). An empirical analysis of the relation between board of director composition and financial statement fraud.Account. Rev., 71, 443-465.

Beekes, W., Pope, P. \& Young, S. (2004). The link between earnings timeliness, earnings conservatism and board composition: evidence from the UK. Corp. Gover., 12(1), 47-59.

Byrd, J. W. \& Hickman, K. A. (1992). Do outside directors monitor managers? Evidence from tender

Bushman, R., Piotroski, J. D. \& Smith, A. (2004). What determines corporate transparency? J. Account. Res., 42(2), 207-252.

Cadbury, A. (1992). Report of the Committee on the Financial Aspects of Corporate Governance. Gee Publishing, London.

Dechow, P., Sloan, R. \& Sweeney, A. (1996). Causes and consequences of earnings manipulation: an analysis of firms subject to enforcement actions by the SEC. Contemporary Account. Res., 13(1), 1-36.

Farber, D. B. (2005). Restoring trust after fraud: does corporate governance matter? The Accounting Review, 80,539-561.

Fama, E. F. \& Jensen, M. C. (1983). Separation of ownership and control. Journal of Law and Economics, 26, 301-326.

Klein, A. (2002). Audit committee, board of director characteristics, and earnings management. J. Account. Econ., 33, 375-400.

Lafond, R. \& Roychowdhury, S. (2008). Managerial ownership and accounting conservatism. J. Account. Res., 46(1), 101-135.

Peasnell, K. V., Pope, P. E. \& Young, S. (2000). Accrual management to meet earnings targets: UK evidence preand post-cadbury. Brit. Account. Rev., 32, 415-426.

Rosenstein, S. \& Wyatt, J. G. (1990). Outside directors, board independence and shareholder wealth. Journal of Financial Economics, 26, 175-91.

Scott. W. R. T. (2009). Financial Accounting Theory.

Skinner, D. J. (1994). Why firms voluntarily disclose bad news. J. Account. Res., 32, 38-60.

Trueman, B. (1997). Managerial disclosures and shareholder litigation. Rev. Account. Studies, 2, 181-199.

Weisbach, M. (1988). Outside directors and CEO turnover. J. Finance. Econ., 20(1/2), 431-460.

Yermack, D. (1996). Higher market valuation of companies with a small board of directors. J. Financial Economics, 40, 185-211. 